\title{
Nucleolar Organizer Region (NORs) in pseudocarcinomatous hyperplasia and squamous cell carcinoma of the oral mucosa
}

\author{
Department of Pathology, Faculdade de Medicina, \\ Universidade Estadual de Campinas - São Paulo, Brazil
}

\begin{abstract}
Counts of nucleolar regions (NORs) demonstrated by a silver staining technique in paraffin sections, have been used to distinguish benign from malignant lesions. AgNORs were studied in 24 biopsies from oral cavity ( 5 cases of normal oral mucosa, 5 of pseudocarcinomatous hyperplasia and 14 of squamous cell carcinoma, subdivided according to degree of differentiation: 5 grade 1,5 grade 2 and 4 grade 3 ) to find whether they were helpful in distinguishing pseudocarcinomatous hyperplasia due to chronic parasitic infections from squamous cell carcinoma. Two methods of counting AgNORs were used: $(A)$ a simpler one which counts nucleolar clusters (AgNU) and satellite AgNORs and the other (B) counting all individual AgNORs, including those within AgNUs. In both methods the lowest mean values were observed for grade 3 carcinoma, while the highest belonged to grade 2 carcinoma. The

simpler method (A) was the most useful because AgNU counts showed significant difference when pseudocarcinomatous hyperplasia was compared with grade 1 and 2 carcinomas, which are the most difficult to discriminate from it. However the overlapping of values render the technique of limited use in individual cases.
\end{abstract}

UNITERMS: AgNORs. Oral carcinoma. Mouth. Oral mucosa. Pseudocarcinomatous hyperplasia. Squamous cell carcinoma.

\section{INTRODUCTION}

$\mathrm{P}$ seudocarcinomatous hyperplasia of the upper respiratory and digestive tracts is common in developing countries due to chronic parasitic infections, particularly paracoccidiodomycosis and leishmaniosis, and may simulate carcinoma clinically and histologically (7)

\section{Address for correspondence:}

Albina Messias de Almeida Milani Altemani

Departamento de Anatomia Patológica, FCM-UNICAMP

Caixa Postal 6111

Campinas - SP - Brasil - CEP 13081-970
Counts of nucleolar organizer regions (NORs) demonstrated by a silver staining technique in paraffin sections, have been used to distinguish benign from malignant lesions $(3,4,8,11)$. NORs are chromosomal segments in which ribosomal RNA (rRNA) is encoded (13). They are responsible for the development of nucleoli, into which they project large loops of DNA (12).

There is only one previous study applying AgNORs counts to distinguish pseudo-carcinomatous hyperplasia and oral squamous cell carcinoma (2). However the authors did not consider the degree of differentiation of the squamous cell carcinoma in their study. The welldifferentiated carcinoma is the most difficult to discriminate from pseudocarcinomatous hyperplasia (7).

Our objective was to examine whether AgNORs reliably distinguish these two diseases. 


\section{MATERIAL AND METHODS}

The material consisted of 24 biopsies from the oral cavity; 5 samples of normal oral mucosa, 5 cases of pseudocarcinomatous hyperplasia due to paracoccidioidomycosis and 14 of squamous cell carcinoma. This latter was subdivided according to degree of differentiation in: grade 1 (5 cases) - carcinomatous cells were predominantly of mature squamous type showing relatively slight atypia, grade 2 ( 5 cases) - many carcinomatous cells were atypical and devoid of prickles, grade 3 ( 4 cases) - all carcinomatous cells were atypical without recognizable intercellular bridges and keratinization was absent. All specimens were formalinfixed. Paraffin-embedded sections 3 um-thick were stained with the AgNOR procedure, according Ploton et al (10), with incubation time of $30 \mathrm{~min}$. The sections were viewed under oil immersion (C 100) by a single observer (AMA). One hundred nuclei were randomly examined, but in normal mucosa, pseudo-carcinomatous hyperplasia and grade 1 carcinoma only basal and parabasal cells were taken into account. Two methods of counting were used. In the simpler method (A) nucleolar clusters were counted as a single AgNOR, irrespective of the number of dots within the nucleolus, and so this gave a total representing the number of dissociated, satellite AgNORs (sAgNORs) and nucleolar clusters (AgNUS). The second method (B) involved counting total AgNORs, including those aggregated within AgNUS clusters. The data were analyzed by the Kruskall-Wallis test and Wilcoxon sum rank test.

\section{RESULTS}

The findings in each of the five diagnostic categories, using both counting methods are shown in table 1. All groups showed a wide variation in their counts (Fig. 1 and 2 ). The highest means were of the grade 2 carcinoma in both methods, while the lowest means were of the grade 3 carcinoma.

In relation to the method $\mathrm{A}$ the AgNUS counts showed significant difference when pseudocarcinomatous hyperplasia was compared with grade 1 carcinoma, grade 2 carcinoma and normal mucosa, but not with grade 3 carcinoma. This significant difference was due to lower mean of $\mathrm{AgNU}$ found in pseudocarcinomatous hyperplasia. However neither total AgNORs counts nor sAgNORs counts were helpful to distinguish pseudocarcinomatous hyperplasia from grade 1 carcinoma. The former type of counting showed significant difference only between pseudocarcinomatous hyperplasia and grade 2 carcinoma, while the latter did not show significant differences among any groups at all. Concerning method $\mathrm{B}$ the means of AgNORs counts were not significantly different between pseudocarcinomatous hyperplasia and the other groups, except for grade 3 carcinoma which had the lowest mean of AgNORs.

The morphological study of the AgNORs showed that only grade 2 and 3 carcinomas had distinctive patterns. Grade 2 carcinoma presented several AgNUS of different sizes and shapes and usually rich in dots, together with frequently dissociated satellite AgNORs. In contrast grade 3 carcinoma usually had only one AgNU with few or no

Table 1

Mean \pm SD AgNOR counts in normal mucosa and oral lesion

\begin{tabular}{lrlll}
\hline Diagnostic group & \multicolumn{1}{c}{ AgNOR } & AgNU & sAgNOR & AgNORT \\
\hline Normal mucosa & $10.82 \pm 3.58$ & $2.26 \pm 0.34$ & $0.57 \pm 0.25$ & $2.83 \pm 0.45$ \\
Pseudocarcinomatous hyperplasia & $11.60 \pm 2.34$ & $1.73 \pm 0.13$ & $0.42 \pm 0.18$ & $2.15 \pm 0.23$ \\
Grade 1 Carcinoma & $9.59 \pm 2.40$ & $2.42 \pm 0.99$ & $0.46 \pm 0.17$ & $2.87 \pm 1.12$ \\
Grade 2 Carcinoma & $13.47 \pm 2.38$ & $2.95 \pm 0.48$ & $1.53 \pm 0.71$ & $4.48 \pm 1.00$ \\
Grade 3 Carcinoma & $4.99 \pm 1.43$ & $1.53 \pm 0.18$ & $0.38 \pm 0.11$ & $1.91 \pm 0.26$ \\
\hline
\end{tabular}




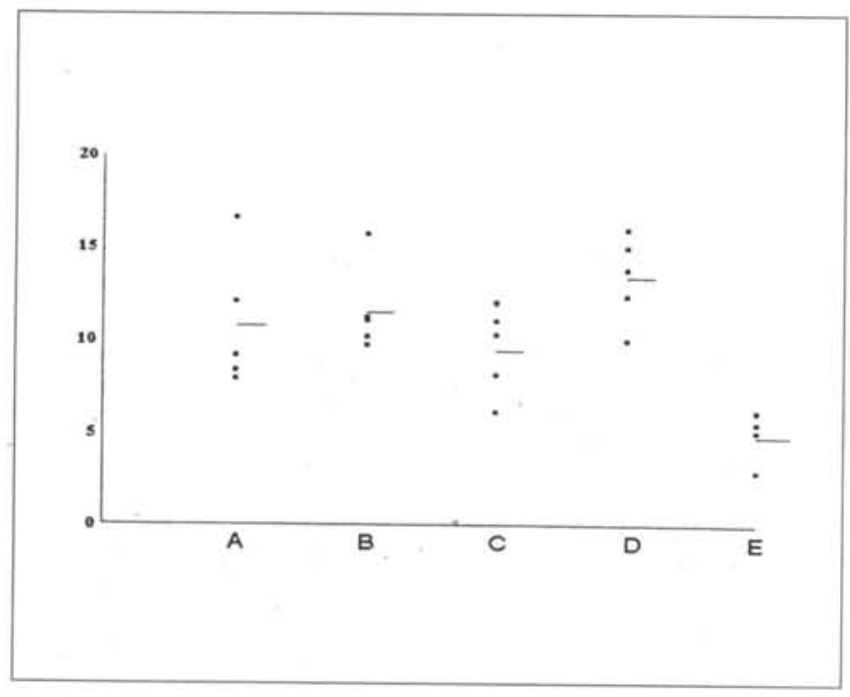

Figure 1 - Mean AgNOR counts per case in each group studied. A - Normal mucosa, B - pseudocarcionomatous hyperplasia, C grade 1 carcinoma, D - grade 2 carcinoma, E - grade 3 carcinoma.

dots (AgNORs) inside it. Pseudocarcinomatous hyperplasia and grade 1 carcinoma did not show distinctive morphological patterns of AgNUs or AgNORs. Both had few nucleoli, usually increased in size, rich in dots and rare dissociated AgNORs (Fig. 3).

\section{DISCUSSION}

Pseudocarcinomatous hyperplasia may occur in skin and mucous surfaces associated to chronic proliferative inflammatory processes, edges of chronic ulcers and granular cell tumor (7). The histological study of the lesion shows irregular proliferation of the epithelium, with invasion of the submucosa by epithelial masses and strands, with horn-pearl formation and frequently numerous mitotic figures. Multiple biopsies of these lesions and detailed clinical data may be necessary for differentiation of squamous cell carcinoma, particularly grade 1 (well-differentiated) carcinoma, which shows relatively slight cellular atypias (7).

Infectious diseases causing chronic proliferative inflammatory process associated to pseudocarcinomatous hyperplasia in mucous membranes of the upper digestive and respiratory tracts occur frequently in developing countries. The histological differentiation of this type of

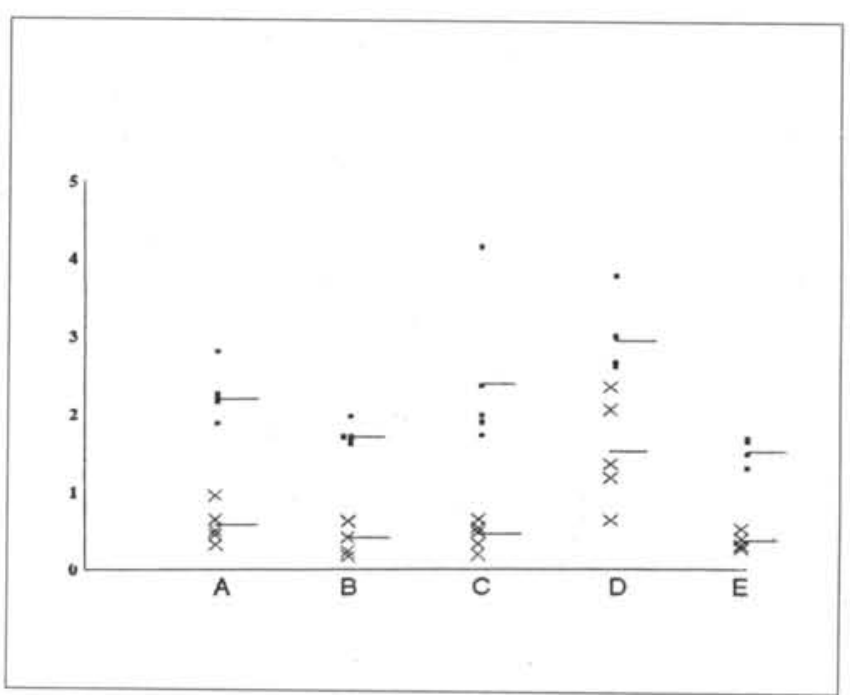

Figure 2 - Mean AgNU and sAgNOR counts per case in each group studied. A - normal mucosa, B - pseudocarcinomatous hyperplasia, C - grade 1 carcinoma, D - grade 2 carcinioma, E grade 3 carcinoma.

pseudocarcinomatous hyperplasia and well differentiated carcinoma is a common problem in routine surgical pathology and relies on the identification of infectious agents in small specimens of biopsies.

Chungpanich and Smith (2) suggested that the AgNOR counts could be used as a reliable index for distinguishing oral squamous cell carcinoma and pseudocarcinomatous hyperplasia due to papillary hyperplasia, denture induced fibrous hyperplasia and granular cell tumor. The authors counted all AgNOR dots per nucleus and found a significantly lower mean of AgNOR counts in pseudocarcinomatous hyperplasia.

However we found that AgNOR counts were of limited value to distinguish pseudocarcinomatous hyperplasia of infections origin and grade 1 and 2 carcinoma.

It should be noted that we used two methods of AgNORs counts: one of them is simpler and more easily reproducible and the other more time-consuming and more difficult to reproduce $(6,9)$, similar to one used by Chungpanich and Smith. The simpler method, which counts nucleolar clusters ( $\mathrm{AgNU}$ ) as a single $\mathrm{AgNOR}$ was the most helpful to discriminate between pseudocarcinomatous hyperplasia and grade 1 and 2 carcinoma. The mean AgNUS counts was significantly lower in the former lesion. The more time-consuming method, counting total AgNORs dots, including those 

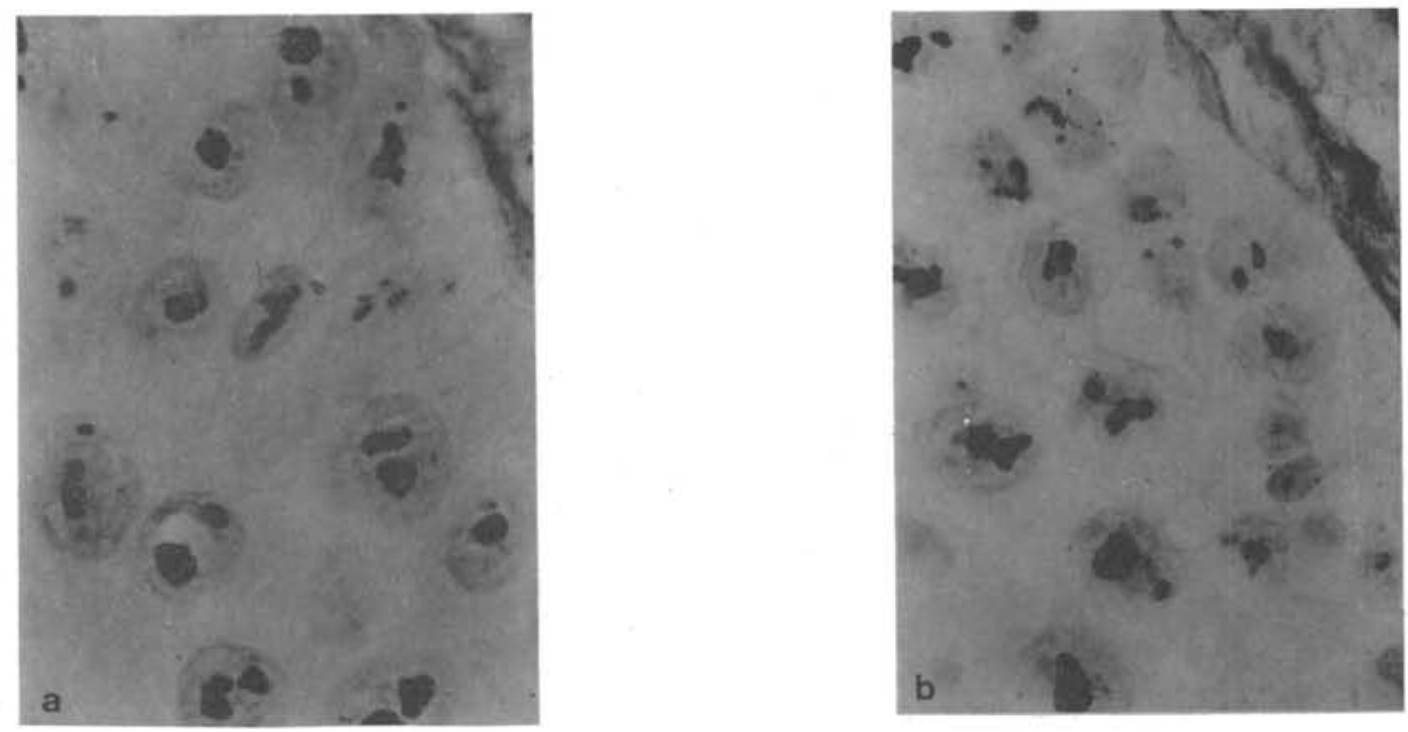

Figure 3 - Pseudocarcinomatous hyperplasia $(A)$ and grade 1 carcinoma $(B)$ did not show distinctive morphological patterns of AgNUs or AgNORs.

aggregated within $\mathrm{AgNU}$ clusters did not show significant difference between pseudocarcinomatous hyperplasia and grade 1 and 2 carcinoma. The simpler method has been also useful in other organs and tumors $(1,5,8)$.

However, in spite of the mean AgNU counts being significantly lower in pseudocarcinomatous hyperplasia, we found some overlapping values between the groups. Therefore this index was of limited use for the diagnosis of individual cases.
In addition, we did not observe morphological differences of AgNORs and AgNUS between pseudocarcinomatous hyperplasia and grade 1 carcinoma, which are the most difficult to distinguish in specimens of surgical pathology.

In conclusion, AgNORs counts were of limited value for the differential diagnosis between pseudocarcinomatous hyperplasia of infectious origin and squamous cell carcinoma of the oral cavity.

\section{RESUMO}

Introdução e Objetivos: Regiōes organizadoras do nucléolo podem ser detectadas através do nitrato de prata em secçōes de parafina. A contagem de AgNORs tem sido utilizada para distinguir entre lesōes benignas e malignas. Material e Métodos: AgNORs foram contados em 24 biopsias da cavidade oral ( 5 casos de mucosa oral normal, 5 de hiperplasia pseudocarcinomatosa e 14 de carcinoma epidermóide, subdivididos segundo o grau de diferenciação: 5 grau $1 ; 5$ grau 2 e 4 grau 3) para verificar sua utilidade no diagnóstico diferencial entre hiperplasia pseudocarcinomatosa, secundária a infecçōes parasitárias crônicas, e carcinoma epidermóide. Foram usados dois métodos de contagem de AgNORs: um mais simples(A), que conta os agregados nucleolares (AgNU) e AgNOR satélites e o outro (B) que conta todos os AgNORs, inclusive aqueles dentro do AgNUs, Resultados e Conclusão: Em ambos os métodos as médias mais baixas foram do carcinoma grau 3 e as mais altas do carcinoma grau 2. O método mais simples (A) foi o mais útil, pois a contagem de AgNU mostrou valores significantemente diferentes quando comparou-se hiperplasia pseudocarcinomatosa e carcinomas graus 1 e 2 , que são os mais difíceis de distinguir da hiperplasia. Entretanto, devido à sobreposição de valores a técnica foi de utilidade limitada em casos individuais. 


\section{REFERENCES}

1. ALLEN, J.P. \& GALLIMORE, A.P. - Nucleolar organizer regions in benign and malignant glandular lesions of the cervix. J Pathol 166:153-156, 1992.

2. CHUNGPANICH, S. \& SMITH, C.J. - Nucleolar organizer regions (NORs) in hyperplastic lesions and squamous cell carcinomas of the oral mucosa. J Dent Rev 68:597 (only), 1989.

3. EGAN, M.J.; RAAFAT, F.; CROCKER, J. \& SMITH, K. Nucleolar organizer regions in fibrous proliferations of childhood and infantile fibrosarcoma. J Clin Pathol 41: 31-3, 1988.

4. EGAN, M.J. \& CROCKER, J. - Nucleolar organizer regions in cutaneous tumours. J Pathol 154: 247-53, 1988.

5. GROTTO, H.Z.W.; LORAND-METZE, I. \& METZE, K. Nucleolar organizer regions in normal hematopoiesis: relationship to cellular proliferation and maturation. Nouv Rev Fr Hematol 3:1-4, 1991.

6. GURI, D.D.; NOTTINGHAM, J.F.; LAWRY, J.; DUNDAS, S.A.C. \& UNDERWOOD, J.C.E. - Silver binding nucleolar organizer regions (AgNORs) in benign and malignant breast lesions: correlation with ploidy and growth phase by DNA flow cytometry. J Pathol 157:307-313, 1989.
7. LEVER, W.F. \& SCHAUMBURG-LEVER, G. Histopathology of the skin. Philadelphia, JB Lippincott, 559-560, 1990.

8. MAURI, F.A.; FERRERO, S.; BARBARESCHI, M. et al. AgNOR distribution in normal dysplastic laryngeal mucosa and in laryngeal epidermoid carcinomas. Pathologica 82:493-497, 1990.

9. MAURI, F.A.; BARBARESCHI, M.; SCAMPINI, S.; FERRERO, S. \& PERRONE, G. - Nucleolar organizer regions in mucinous tumours of the ovary. Histopathology 16:396-398, 1990.

10. PLOTON, D.; MENAGER, M.; JEANNESSON, P.; HIMBER, G.; PIGEON, F. \& ADNETT, J. - Improvement in the staining and in the visualisation of the argyrophilic proteins of the nucleolar organizer region at the optical level. Histochem J 18:5-14, 1986.

11. SANO, K.; TAKAHASHI, H.; FUJITA, S. et al. - Prognostic implication of silver-binding nucleolar organizer regions (AgNORs) in oral squamous cell carcinoma. J Oral Pathol Med 20: 53-56, 1991.

12. UNDERWOOD, J.C.E. \& GIRI, D.D. - Editorial: nucleolar organizer region as diagnostic discriminants for malignancy. J Pathol 155: 95-96, 1988.

13. WALKER, R.A. - Commentary. The histopathological evaluation of nucleolar organizer regions proteins. Histopathology 12: 221-223, 1988.

\section{Errata}

The OriginalArticle "Nucleolar Organizer Region (NORs) in pseudocarcinomatous hyperplasia and squamous cell carcinoma of the oral mucosa" (Rev Paul Med 112(4): 642-645, 1994), was incorrectly published, then we decided to reprint it in full. 